\title{
Between Ruins and Permanence: The Heritage in the Urbanization's Specificity of Goiás (Brazil)
}

\author{
By Luana Nunes Martins de Lima* \\ Everaldo Batista da Costa ${ }^{\dagger}$
}

\begin{abstract}
In Goiás, many cities founded in the mining cycle (colonial period) did not have their heritage recognized, restored or maintained by organs and institutions of preservation, leaving few assets in the urban area. In these cities, history reconstructs the process whereby modern values were fixed in the backcountry. The purpose of this paper is to expose the context of analysis of Goiás's heritage in relation to the colonial urbanization's specificity in this Brazilian state, thus showing how their condition of negligence is the result of processes that can be contextualized in history. The permanence of heritage, however, is latent and does not express itself only through historical materialities maintained in urban space, but above all, by the symbolic practices that nurture this space. The general objective of the doctoral thesis that bases this article, therefore, is to unveil the forms of resistance of the cultural heritage in the cities established for research in Goiás (Pilar, Crixás and Porangatu), as well as the sense of place (placeness) attributed by memory in the symbolic-affective relation of the populations with their heritage.
\end{abstract}

\section{Introduction}

Beyond "a museum" perspective, the material heritage of cities adds historical references and evidences transformations of the urban space in the entire world. The treatment given to cultural heritage of cities and how their image is reproduced has much to reveal about the historical dynamics of urban space, considering different relations and scales.

In studies carried out by geographers and professionals of similar areas, we identify three possibilities that compromise the existence/resistance of this heritage. In the first one, heritage is changed by modernization, having its elements little by little substituted with new forms and functions in the city $^{1}$. In the second, heritage is incorporated into the logic of the market and becomes the base for the staging and the aesthetics of tourist places ${ }^{2}$, resulting in a process that assigns another signification to these places.

In the third, heritage is simply neglected (or "forgotten") in cities that have maintained a certain economic, social and cultural distance from other cities

\footnotetext{
${ }^{*}$ Professor, Universidade Estadual de Goiás, Brazil.

${ }^{\dagger}$ Professor, Universidade de Brasília, Brazil.

1. F. Choay, A alegoria do patrimônio [The allegory of heritage] (São Paulo: UNESP, 2001).

2. E. Batista da Costa, Cidades da Patrimonialização Global: simultaneidade totalidadeurbana - totalidade-mundo [Cities of Global Heritage: simultaneity totality-urban-totalityworld] (São Paulo: Humanitas, 2015).
} 
that were developing centralities ${ }^{3}$. This reflection on the last possibility opens the way to problematize the heritage of Goiás cities, as well as pointing to other possibilities, namely the resistance that confronts the forgetfulness of the place and the heritage. This is the central idea of the thesis project in development, entitled "Place and memory: the heritage in Goiás between the forgetfulness and the resistance" ${ }^{4}$.

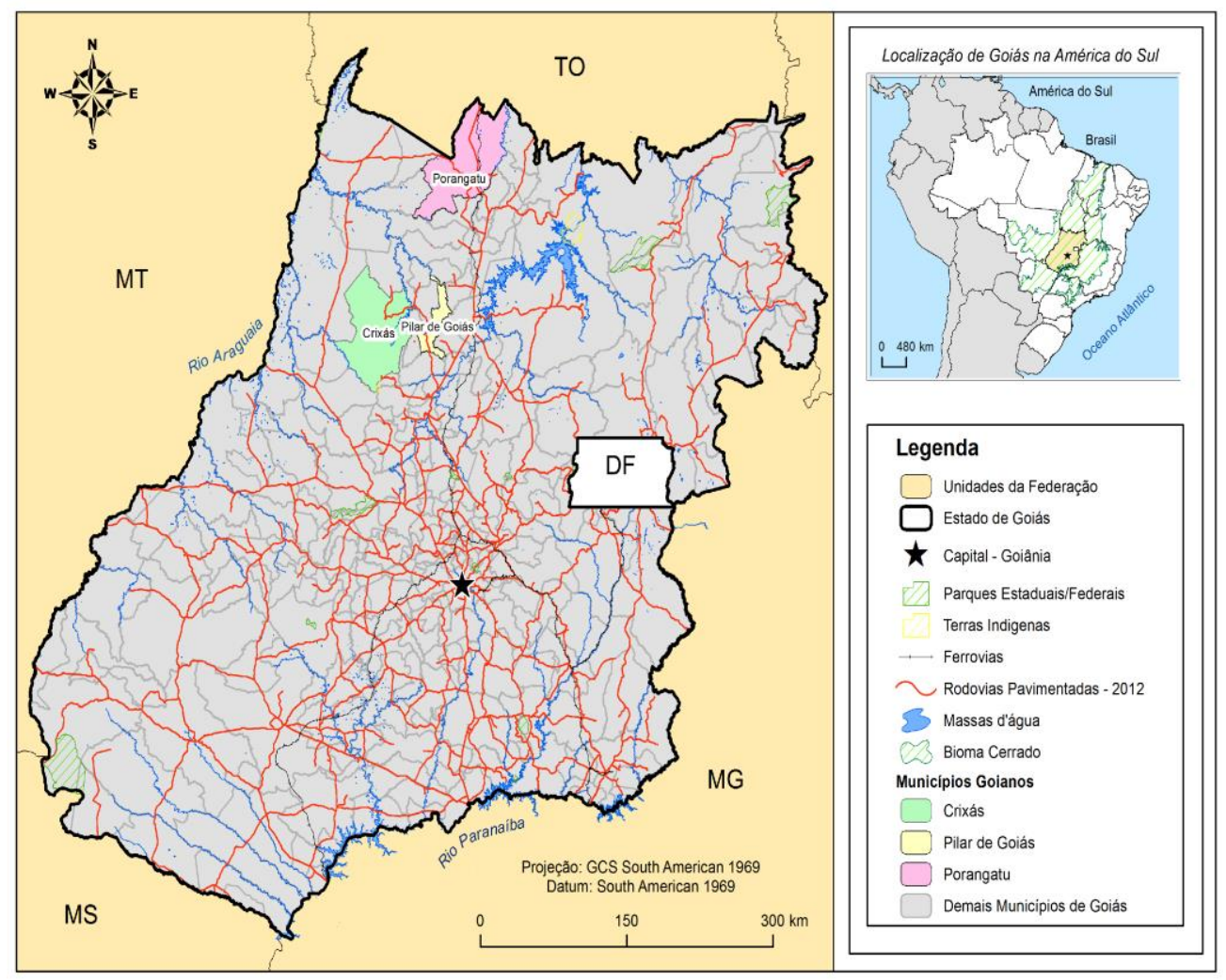

Figure 1. Location Map of the Cities Pilar de Goiás, Crixás and Porangatu, in the State of Goiás, Brazil

Elaboration: Sílvio Braz de Sousa. Organization: Luana Nunes Martins de Lima. 2016.

In this paper we analyzed the case of these three cities: Pilar and Crixás, located in the region of the São Patrício Valley in the central region of the state, and Porangatu, in the north region of the state, in which occupation and settlement revolve around mining.

The choice of these cities can be explained initially by the evidence of an ongoing process of abandonment of heritage by the public authorities, the preservation agencies, and the local community itself, something which is also notable in other historic cities in Goiás.

3. M.T. Duarte Paes, "Trajetórias do patrimônio cultural e os sentidos dos seus usos em Paraty (RJ)" ["Trajectories of cultural heritage and the meanings of its uses in Paraty (RJ)"], Resgate - Revista Interdisciplinar de Cultura 23, no. 30 (2015): 105-118.

4. Thesis defended and approved by the Postgraduate Program in Geography of Universidade de Brasília (UnB) in 2017. This idea also inserts the project "Cultural Heritage in Goiás: Cities seized by memory", registered and realized in Universidade Estadual de Goiás (UEG). 
Crixás was founded between the years of 1726 and 1734 with the denomination of Arraial de Nossa Senhora da Conceição. It has a population of 15.760 inhabitants, according to demographic census of the Brazilian Institute of Geography and Statistics (IBGE) ${ }^{5}$. In Crixás, only one good material was singly registered, with some reminiscences of material culture in the urban area.

The settlement of Porangatu originated from the discovery of gold, probably between 1744 and 1754. The village became known as Arraial do Descoberto da Piedade. The approximate population of the municipality is 42.355 inhabitants, constituting a centrality in the northern region of the state of Goiás. In Porangatu, the perimeter of the historic site was registered by the municipal government, but the law of registration does not apply in local practice, meaning that only a few traces of the original colonial architecture remain ${ }^{6}$.

Pilar de Goiás was founded in 1741, with the denomination of Arraial de Nossa Senhora do Pilar, being one of the most gold-producing settlements in Goiás. After a long period outside the trade route, the city stagnated. Today, its approximate population is 2.773 inhabitants $^{7}$. In Pilar de Goiás, where there is a greater concern, the area registered is in the process of being studied in order to ratify the areas of real interest for the preservation of the National Historical and Artistic Heritage Institute (IPHAN), but most of the historic buildings have collapsed since the 1960s. In the three cities, some goods have been repurposed for cultural activities, a few have been restored and registered, many are still in ruins, deteriorating or destroyed in favor of other types of buildings.

The objective of this research is to understand, from an analysis of Goiás in its position in the national scenario, the factors that led the historical cities of Goiás to the condition of "forgetfulness" in the face of the economic period called "decadence" and project of modernization that developed in Brazil in the 19th and 20th centuries. The correlation of this trajectory with the dynamics of public heritage policies projected nationally and internationally can indicate negligence and valuation as counterpoints.

In addition, it is necessary to reveal a heritage that is not considered as heritage by locating the resistances: social relations, symbols, memories and experiences lived in the totality of the city, with the purpose of understanding the heritage from collective and plural signification.

5. Instituto Brasileiro de Geografia e Estatística (IBGE), Cidades [Cities], 2010, http:// bit.ly/2zvVuPS, (accessed January 17, 2015).

6. Ibid., http://bit.ly/2lbHx7I, (accessed January 17, 2015).

7. Ibid, http://bit.ly/2xgvEPg, (accessed January 17, 2015). 


\section{Methodology}

\section{$1^{\text {st }}$ Stage - Bibliographic Review}

The first stage of the research consisted of conceptual and thematic revision for the theoretical-methodological foundation and operationalization of the concepts. The survey, reading and bibliographic review were delimited in order to emphasize the theoretical-conceptual bases to be adopted.

The bibliographic review is distributed in thematic axes that include the reflection of various areas of knowledge such as geography, history, architecture and urbanism, anthropology and sociology, focusing on the concepts of resistance, memory, heritage and place. The bibliographical research was carried out in the articles of periodicals, books, dissertations and theses that treat these themes and concepts.

$$
2^{\text {nd }} \text { Stage - Documentary Research and Survey }
$$

The second stage was a survey of the cultural goods found in Goiás by IPHAN and the state from the 1930s to the present, following a mapping, by means of fieldworks and documentary research (municipal laws of registration, urban plans, documents regarding the opening or requests of administrative processes for registration, projects submitted to the safeguarding of material and intangible heritage, travel reports, correspondence exchanged between local managers, regional superintendents and others). We identified the elements of heritage that are still present in the cities, and whether or not they are included in the official list of goods of conservation interest, in order to make a reading of their current situation. This first survey will involve the representative elements of memory of cities, such as buildings, architectural ensembles, monuments, churches, squares, fountains, bells, museums, festivities and other traditional elements.

\section{$3^{\text {rd }}$ Stage - Participant Research}

The fieldwork in the cities was conducted with the methodological approach of "participant research" 8 , and oral history ${ }^{9}$. These methodologies were fundamental to identifying which are the elements that denote resistance of the patrimony from the local memory, what is the representativeness of this heritage for its inhabitants in the constitution of the place, and how the sense of place, once strengthened by memory, contributes to safeguarding the heritage and history of these cities.

Fieldwork surveys were carried out during different periods of the year, focusing on private visits to the sites considered as architectural heritage and monuments, sources of collections of images and photographs of the cities

\footnotetext{
1990).

8. C. R. Brandão, Pesquisar-Participar [Research - Participate] (São Paulo: Brasiliense,

9. L. de Almeida Neves Delgado, História Oral: memória, tempo, identidade [Oral History: memory, time, identities] (Belo Horizonte: Autêntica, 2010).
} 
in other periods, previously selected residents and the agents responsible for cultural policies. In addition, the periods of the fieldwork surveys were also selected according to the occurrence of expressive cultural manifestations in the cities, such as the festivities of Nossa Senhora do Pilar and the Cavalhadas ${ }^{10}$ in Pilar de Goiás, the celebrations of the Christmas cycle that include the traditional "novenas" and visitation of cribs in Pilar, the festivities of the "Divino Espírito Santo" in Crixás and Pilar de Goiás, the festivities of "Boa Vizinhança" and the "Arraiá do Descoberto" in Porangatu. The fieldwork surveys involved the following:

1) Direct unsystematic observation ${ }^{11}$;

2) Semi-structured thematic interviews ${ }^{12}$;

3) Narrative interviews ${ }^{13}$;

4) Photo-interview ${ }^{14}$.

For all interview modalities, sampling was not defined at the beginning of the research, because we considered as a possibility the pre-selection of people that would be nuclear and would serve as a reference for selection of the other interviewees ${ }^{15}$.

We conducted 35 interviews: 13 in Pilar de Goiás, 13 in Crixás, and 9 in Porangatu. The project was submitted and approved by the Research Ethics Committee of the Institute of Human Sciences at the Universidade de Brasília. Before the interviews, we presented the Informed Consent Form (TCLE).

For the interviews we used oral history techniques: preparation of scripts; conducting interviews; processing and analysis of interviews; transcription; fidelity conference and thematic content analysis. It is the objective of this methodology to emphasize the studied phenomenon in a way that allows us, through orality, to offer qualitative interpretations of historical-social processes. "Oral history, when interested in orality, seeks to highlight and focus its

10. "Cavalhadas" consist of a representation of the Crusades fought in the Iberian Peninsula against the advance of the Arabs in the European territory in century IX. More specifically, they resume the medieval tournaments and fights between Moors and Christians. The celebration is a spectacle of colors, sounds, symbols and revolves around equestrian presentations lasting two to three days. Cavalhadas are composed of twelve "Moorish" knights and twelve "Christian" knights, dressed in the predominant colors of red and blue, respectively. The choreography symbolizes the struggle, up to the moment of the Christian conquest, when the Moors surrender, "convert" to Christianity and are "baptized."

11. M. de Andrade Marconi and E.M. Lakatos, Metodologia Científica [Scientific Methodology] (São Paulo: Atlas, 2004).

12. U. Flick, Introdução à pesquisa qualitativa [Introduction to qualitative research] (Porto Alegre: Artmed, 2009).

13. Ibid.

14. J. de Souza Martins, Sociologia da Fotografia e da Imagem [Sociology of Photography and Image] (São Paulo: Contexto, 2008).

15. Delgado, História Oral: memória, tempo, identidade, 2010. 
analysis on the vision and version that emanate from the inner and deepest experience of social actors". 16

\section{About the Ruins and the Permanence}

The cultural heritage of many historical cities in Goiás is embedded in a condition of "forgetfulness", the result of historical processes that still marginalize it in the present days. Such processes can be located in a periodization ${ }^{17}$. Initially, there is the mark called "economic decadence", to which many cities were subjected in the post-mining period and supposedly caused population decrease, as well as the abandonment of innumerable residences and other types of buildings.

The ways of understanding the heritage in Goiás and its present condition inevitably pass through the "paths of the gold". The historical root of the urbanization of the interior of Goiás (Sertão Goiano ${ }^{18}$ ) came from colonial status, which, in the search for gold and precious stones, extended from Minas Gerais, in the Parnaíba basin, to the Araguaia-Tocantins valley, where were located the mines called "Minas Goyazes".

It is the procedural relationship of the colonial enterprise with the territory of the "sertão" that genetically creates a specificity in the process of urbanization of Goiás, because it was what saw, verified and reported the differentiation of "places-Brazil", specifically about what refers to the "sertão", in which nature and human, from vegetable species, animals, indigenous, and after miners, faced the exuberance of the forests and the spicy sun of the plateau, founded a society, in the originality carrier of its signs of the "sertão", that weaved a urbanization whose essential aspect is its link with the "sertaneja" rurality, in which the most characteristic geographical unfolding was the isolation. ${ }^{19}$

This rural essence and the image of isolation that characterized the cities of the interior of Goiás for a considerable time subordinated the project of nationality that appeared on the scale of the nation. Or was it the contrary?

16. J. E. Aceves Lozano, "Prática e estilos de pesquisa na história oral contemporânea" ["Practice and styles of research in contemporary oral history"] in Usos e abusos da história oral [Uses and abuses of oral history], ed. Marieta de Moraes Ferreira and Janaína Amado (Rio de Janeiro: FGV, 2006), 16.

17. From a methodological point of view, it is necessary to situate the role of "events" as demarcation of patrimonialization, as Costa (2015) suggests. According to Milton Santos (2006), events are not just facts but, above all, ideas. The supposed condition of economic and cultural regression of many cities in the post-mining period must be evaluated from the historical generalities found in the particularities of regional researches.

18. Area of countryside in Brazil, considered geographically isolated and endowed with specific cultural characteristics.

19. E. F. Chaveiro, A Urbanização do Sertão Goiano e a Criação de Goiânia [The Urbanization of the Sertão of Goiás and the creation of Goiânia] in O Espaço Goiano: abordagens geográficas, ed. Horieste Gomes (Goiânia: AGB, 2004), 97. 
The fact is that the unfolding of bandeirantism ${ }^{20}$ culminated in the characterization of the cities of the "sertão" of Goiás, and in their specific form of occupation and urbanization, they were, first, objects of denial and contempt for the foreign look, and later, they did not correspond to the modernist ideas which determined the norms in the Brazilian republican period.

Because of the geographical and settlement conditions, Goiás gradually had its cultural characteristics molded under very peculiar conditions, also considering the influence of different Iberian values that blended into the black and indigenous culture. The baroque of Goiás refers to a new cultural expression and behavior, as a result of this gathering of peoples in the search for gold and haste.

The production of gold, which could make possible new artistic and urbanistic compositions of production in the region, was sent to Portugal in the form of fifths, or was smuggled, leaving little to the urban nuclei that were formed. The artistic opulence of the baroque was restricted, while the gold collected from the rivers of the region greatly served the sumptuous altars of Bahia and Rio de Janeiro.

There has not even been time for some social segments to enjoy the abundance and leisure, that could allow "the spirits to wander". From the eighteenth century, with the exception of some churches and a few monuments and buildings, the artistic legacy of colonial Goiás was small, despite being expressive. The bad realities of daily life, the effort expended on enrichment and survival, exhausted the time and energy of those who moved to the empty Goias. The immense distances, the isolation of the urban nuclei, the instability and the turbulence prevented the concentration of craftsmen, as, for example, those who made possible the development of the Minas Gerais baroque. ${ }^{21}$

With the depletion of deposits of gold, this condition of relative isolation would be associated with the fact that natural conditions conducive to mining were not the same as those conducive to the capital supply trade and the export of agricultural products, a fact which maintained the economic interests of Brazil focused on the expansion of the central-southern provinces. Villages and settlements have become empty by abandonment, and today they are transformed in rubble carelessly. As a consequence, these cities were on the fringes of the development imposed by the idea of progress

20. Bandeirantism (relative to flag) was the movement begun in the sixteenth century to enter the South American "sertões" (country interior) in search of mineral wealth, especially gold and silver, abundant in Spanish America, indigenous to slavery or extermination of quilombos. They contributed, in large part, to the territorial expansion of Brazil beyond the limits imposed by the Treaty of Tordesilhas, occupying the Center West and the South of Brazil. Most of the bandeirantes were descendants of the first and second generation of the Portuguese in São Paulo, and the captains of the flags of varied European origins. They discovered abundant deposits of gold in Minas Gerais, Goiás and Mato Grosso.

21. L. Castello Branco Ferreira de Freitas, "Goiás e Goianidade" ["Goiás and Goianity"], Aphonline 1, no. 1 (2011): 57. 
arising from the Republic, in which Brazil was being announced as a "country of the future", responsible for generating radical urban reforms in several cities.

The slogans of progress, modernization and territorial integration give the tonic of an imagined nation in Imperial Brazil, which sought to materialize throughout the twentieth century at the expense of the selection of what was intended as symbols for national identities. Of course, these cities of Goiás were not selected, perhaps because they presented an architecture considered "simple" and "poor", within artistic parameters that favored opulence and sumptuousness as what would represent the nation-state ${ }^{22}$.

In the "Estado Novo", the conception of historical heritage, coupled with the modernist ideals of achieving a national identity, crystallized great monuments and works of art that would give consistency to the so-called Brazilian culture, while the heterogeneous collective memories of many cities and social groups were suppressed in institutionalized history.

The idea of progress and development spread during this period makes the government's decisions in the interior of Brazil selective and negligent, since projects such as the "March to the West", for example, encouraged migration to areas that produced feedstock and low-cost foodstuffs to subsidize the implantation of industrialization in the southeast region. In Goiás, only the south and southwestern regions were intensely developing their economy and infrastructure in this period.

The selectivity imposed in the process of modernization of the Brazilian territory and in the aesthetic variants that projected some colonial cities, makes many social groups and urban nuclei "forgotten". ${ }^{23}$

Nowadays, this forgetfulness is much more due to the exclusion of these cities in heritage policies, the absence of a democratic policy of historical heritage, added to the relative abandonment of the material heritage that still exists.

In spite of a clear commercial logic to the enactment of patrimony places, strengthened by institutional recognition, our intention is to understand how this heritage was produced and how it is thought about within the history of the place, through the personal history of the people who live there. The value of heritage is in the collective memory. It is endogenous to the history of its inhabitants and often this value does not extrapolate the space of the local scale.

There is a clear confrontation between the sense of forgetfulness in the perspectives presented (modernization and negligence of material heritage), and the sense of resistance, which is set in the present of these historic cities in the relations lived by the populations in their places of memory. Identifying the elements that express the resistance of the patrimony in the face of this process of "forgetfulness" is something that deserves an accurate analysis. The memory, stimulated by these patrimony places, must be interpreted in its intimate relation with the place.

22. E. B. da Costa and J. C. Suzuki, "A ideologia espacial constitutiva do Estado nacional brasileiro" ["The constitutive spatial ideology of the Brazilian national state"], Scripta Nova XVLI, no. 418 (2012).

23. Ibid. 
According Yi Fu Tuan, the "place-lifeworld" has the movement of everyday life and history, but is seen above all as a "pause", showing the construction of familiarity by the meeting of experiences in common. It is understood that the symbolic relationship with the place, and with the spaces of the city, is associated with feelings of security, stability, welcome, custom, comfort and the sensation of something known. ${ }^{24}$

Yi Fu Tuan understands the idea of place as a "pause", where identification and affective ties are established, and where you feel the security that could not be found in a space that is not yours. Thus, the relation with the place of the heritage is established in the accommodation of these aspects of permanence and historical continuity, custom, familiarity, by the population of the cities. The heritage confers to the place singularities that make possible such accommodation ${ }^{25}$.

The daily life (lebenswelt) ${ }^{26}$ is an attribute of this spatiality of heritage, which can only be revealed in the place. The "place" approach in the humanist perspective emerged in the $1950 \mathrm{~s}$ as a counterpoint to the rapid changes eroding the rich diversity of places that geographers have described for centuries. In the author's view, modernity would have created "unplaced landscapes", mitigating the geographic identity of older buildings and neighborhoods that were being demolished for new construction, with no connection to local histories. Thus, the emergence of interest in the category of place was contemporary to the increase of interest in the preservation of the heritage ${ }^{27}$.

In the "place" as "lifeworld" appear the senses of belonging, of familiarity, of security, of custom, of memory of the past. Such senses acquire greater expression when the materialities of the place, in its permanence (or absence), become part of the experiences and meanings attributed by its inhabitants ${ }^{28}$.

\section{The Feasts as Heritage of the Place}

With the emergence and institutionalization of intangible cultural heritage, the feasts became manifestations with greater expression at the national and international level. However, the feasts that aroused greater interest to be registered as heritage events were those considered more "exotic", more "colored", or that added a larger contingent of participants, thus differing from celebrations associated with daily life and the common. Few studies have reflected on these singular manifestations by inserting them into a patrimonial language of "work of memory", be it historical or collective.

24. Y.F. Tuan, Topofilia: Um estudo da percepção, atitudes e valores do meio ambiente [Topophilia: A study of the perception, attitudes and values of the environment] (Londrina: Eduel, 2012).

25. Y.F. Tuan, Espaço e lugar: a perspectiva da experiência [Space and place: the perspective of experience] (Londrina: Eduel, 2013).

26. A. Buttimer, "Grasping the dynamism of lifeworld". Annals of the Association of American Geographers 66 (1976): 277-92.

27. E. Relph, Place and Placelessness (Londres: Pion, 1979).

28. Buttimer, "Grasping the dynamism of lifeworld", 277-92. 
IPHAN, since the Charter of Fortaleza in 1997, has been constructing the instruments and implementing actions for the inventory and registration of intangible cultural assets. However, these instruments and actions have always been associated with an essentialist perspective of culture and heritage, which is evident in UNESCO ${ }^{29}$ 's statement that intangible heritage, while maintaining a sense of identity "is particularly vulnerable, once is constantly changing and multiplying its carriers. For this reason, the international community adopted the Convention for the Safeguarding of Intangible Cultural Heritage in 2003". According to this Convention, "intangible cultural heritage" is considered to be:

[...] practices, representations, expressions, knowledge, skills - as well as the instruments, objects, artefacts and cultural spaces associated therewith - that communities, groups and, in some cases, individuals recognize as part of their cultural heritage. This intangible cultural heritage, transmitted from generation to generation, is constantly recreated by communities and groups in response to their environment, their interaction with nature and their history, and provides them with a sense of identity and continuity, thus promoting respect for cultural diversity and human creativity. ${ }^{30}$

For our analysis, however, this institutional view on the treatment of intangible cultural heritage presents a theoretical and methodological problem if we intend to observe the reality in the cities. From the conceptual point of view, culture itself is reordered in the dialectic of everyday life, which is why, in the analysis of intangible heritage, we are not interested in celebrations, forms of expression and knowledge in themselves, which is more or less traditional (in the sense of permanence of the past). We are rather interested in the shared senses and signs, the dynamics of the attribution of meanings and values in the present.

At the moment that the subjects' memories emphasize these meanings and values, it is more noticeable that what moves them is not always the expectation of "rescue", but rather of (re)creation. In this sense, "memory ceases to have a character of restoration and becomes the generating memory of the future". 31

Folias $^{32}$, for example, as a rite of remembrance are not ceremonies that carry objects considered simply as remnants to be preserved. The act of summoning the past ritualistically does not necessarily mean nostalgia.

29. United Nation Educational, Scientific and Cultural Organization.

30. UNESCO, Convention for the Safeguarding of the Intangible Cultural Heritage, Art. 2 (Paris, 2003): 2.

31. E. Bosi, O tempo vivo da memória: ensaios de psicologia social [The living time of memory: social psychology essays] (São Paulo: Ateliê Editorial, 2003): 66.

32. "Folia" is a manifestation of popular Catholicism, in which a group, carrying a flag with the image of the divinity, walks an area, passing from house to house for days. The religious people believe that the flag, which represents the divinity itself, has powers to bless the house that receives it. Besides the sacred, in the ritual there are specific songs, dances and jokes. Also donations are collected for the celebration of the feast. 
"Memory, in its power to revive narratives, is creative, and the memorycommemoration does not operate within a supposed separation between past, present and future. The retrospective is an act of stretching, extension for the future ". 33

It is also important to recognize that "in all these celebrations, belief is inextricably linked to the image and it is captured through the act of remembering and reviving. Here we see that images of the past and the revived knowledge are sustained by ritual performances" ${ }^{34}$. Memory recognizes the rite as a heritage from the past, and the patrimonial value is given by what the "act to celebrate" and the rites and practices themselves mean in the present. And what do they mean in the present? Does the celebration respond to some individual or collective need, or does it fulfill some essential social function (not always clear to the participants themselves)? Answering these questions:

[...] from the inside out, maybe it is preferable to believe that people "live the feast" because it is one among the other symbolic forms so humanly ancestral and essential, through which feelings, knowledge, senses, meanings and the inevitable sociabilities of everyday life are retranslated and re-spoken, solemnly pronounced between prayer, song, dance, procession, pilgrimage, theater, celebration, in short. ${ }^{35}$

For geography, the festivity has become a fruitful field of analysis, because it constitutes and produces dynamic spaces and movements, besides making possible the understanding of discourses about place, defining the specific social and spatial practices of those who carry it out. It allows us "to perceive the specialized signs by which social groups identify themselves in specific geographical contexts that fortify their singularity" ${ }^{36}$.

Today, festivities are referred to as living reminiscences of the past that allow certain continuity, despite the discontinuities that have occurred. Therefore "the feast is transferred as a re-actualization movement of the place consecrated in the collective imagination as the legitimate scenario of the present staging, as a propitious context to reanimate the place of the past $^{\prime 37}$. The place in ruins is remembered with sorrow, while the place that remains is appropriated by symbolic practices that nourish the memory and strengthen the ties of identity.

33. R.V. Melo, "Cerimônias comemorativas em Corumbá de Goiás" ["Commemorative ceremonies in Corumbá de Goiás"] in Entorno que transborda: patrimônio imaterial da RIDE, ed. Thereza Ferraz Negrão de Mello (Brasília: Petrobrás, 2008), 167.

34. Ibid., 166.

35. C.R. Brandão, "De um lado e do outro do mar: festas populares que uma origem comum aproxima e que um oceano e um cerrado separam" ["On one side and the other on the sea: popular festivities that a common origin approaches and that an ocean and a cerrado separete"] in Festas, religiosidades e saberes do Cerrado [Festivities, religiosities and knowledge of the Cerrado], ed. M. de Fátima Oliveira et al. (Anápolis: UEG, 2015), 65.

36. G. Di Méo, La géographie en fêtes [The geography in the feasts] (Paris: OPHRYS, 2001), 27.

37. C. Eckert, "A saudade em festa e a ética da lembrança" ["The homesick in celebration and the ethic of remembrance"], Estudos Feministas 5, no. 1 (1997): 185. 
For the local people, it is not always the longevity that circumscribes certain manifestations as traditional or not, as suggested by institutional perspectives, organs of preservation and many cultural studies. Instead it is precisely this "community of feeling", of these identity references that dialogue with different knowledge (cooking, production techniques, arts, languages, among others) entangled in everyday practices.

We refer to festivities in Goiás, specifically those that we researched in Pilar, Crixás and Porangatu, as important mechanisms of cultural resistance, as they allow the recovery of historical memory, values, traditions and lifestyles of local communities. They are resistances because in the interbreeding between the popular and the religious, they have become vehicles, material supports and spaces of symbolic struggle between various interpretations of the past hierarchically positioned.

Even if the festivities are vulnerable to the imposition of capitalist logic, they produce in the community the desire to affirm their own identity and, in a feedback cycle, stimulate knowledge about heritage and a search to recover their own past more and more. Festivities still allow people to assign symbolic meanings to spaces thereby strengthening their connections. They appropriate the patrimonial spaces while the patrimony materializes the affective senses of the festivities.

Often, personal devotions become motives of the great gatherings of people. Finally, the festivities enter in the religious calendar and become part of everyday urban life. Families take turns in devotions to their own divinities and commitments to keep family traditions alive. There are various festivities that constitute an intangible heritage in these cities. For now, we present only a few more significant traditions, which put the population of cities in contact with the space of material heritage.

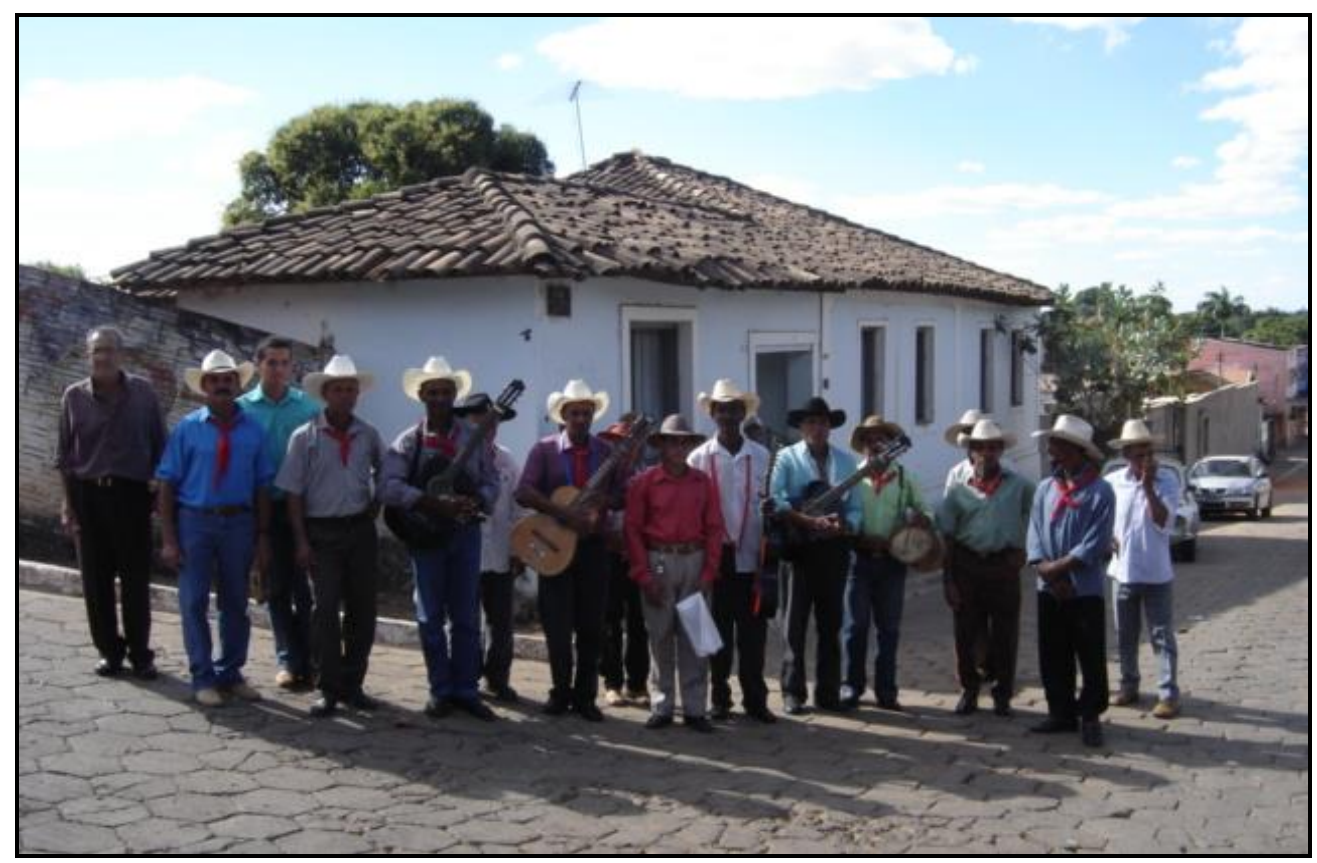

Figure 2. Circuit of Folia of Divino Espirito Santo, in Crixás (Goiás, Brazil) Source: Rômulo Xavier de Lima, 2011. 


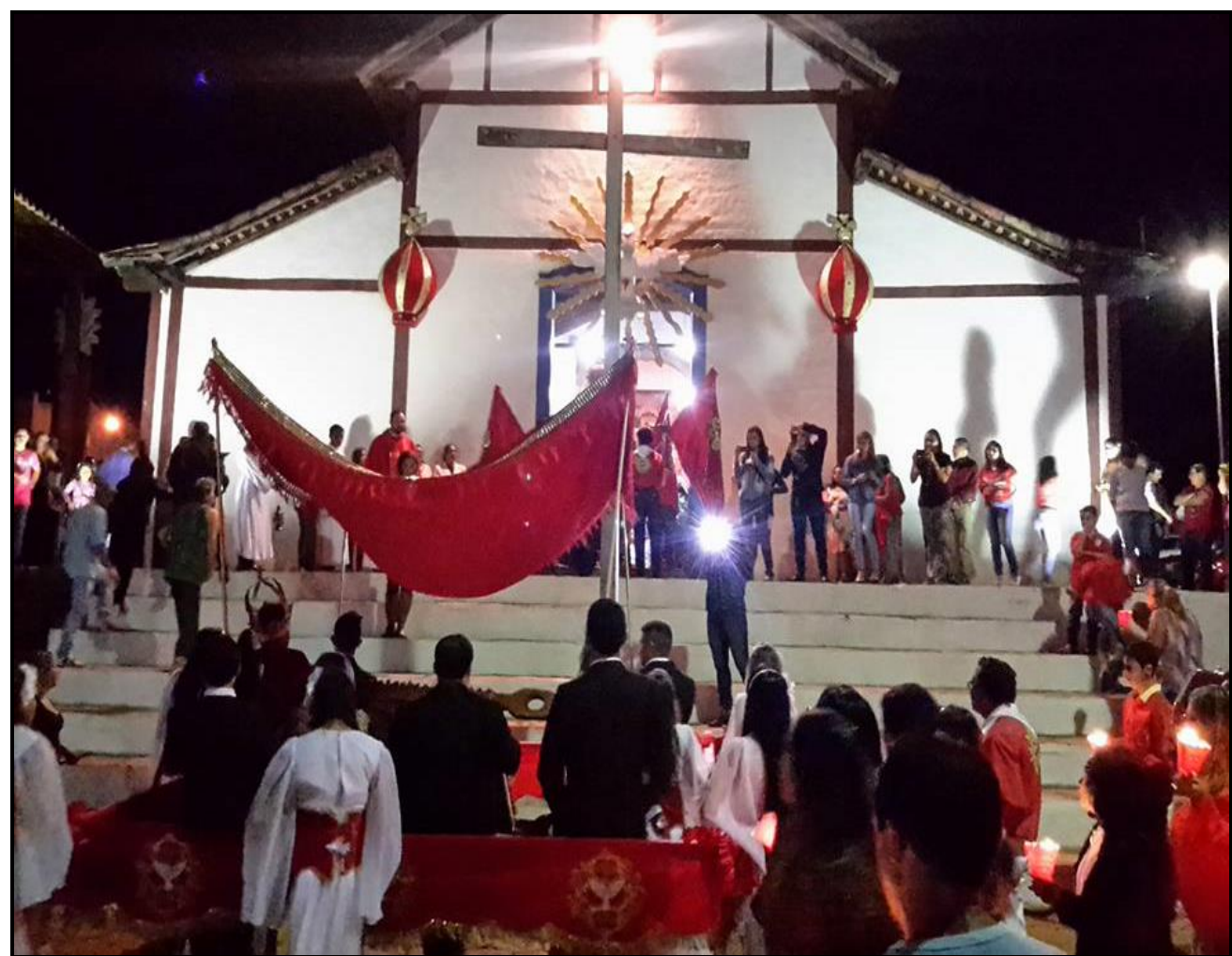

Figure 3. Representation of the Empire's Court of the Divino Espirito Santo, in Pilar de Goiás (Goiás, Brazil)

Source: Rogério Ferreira, 2015.

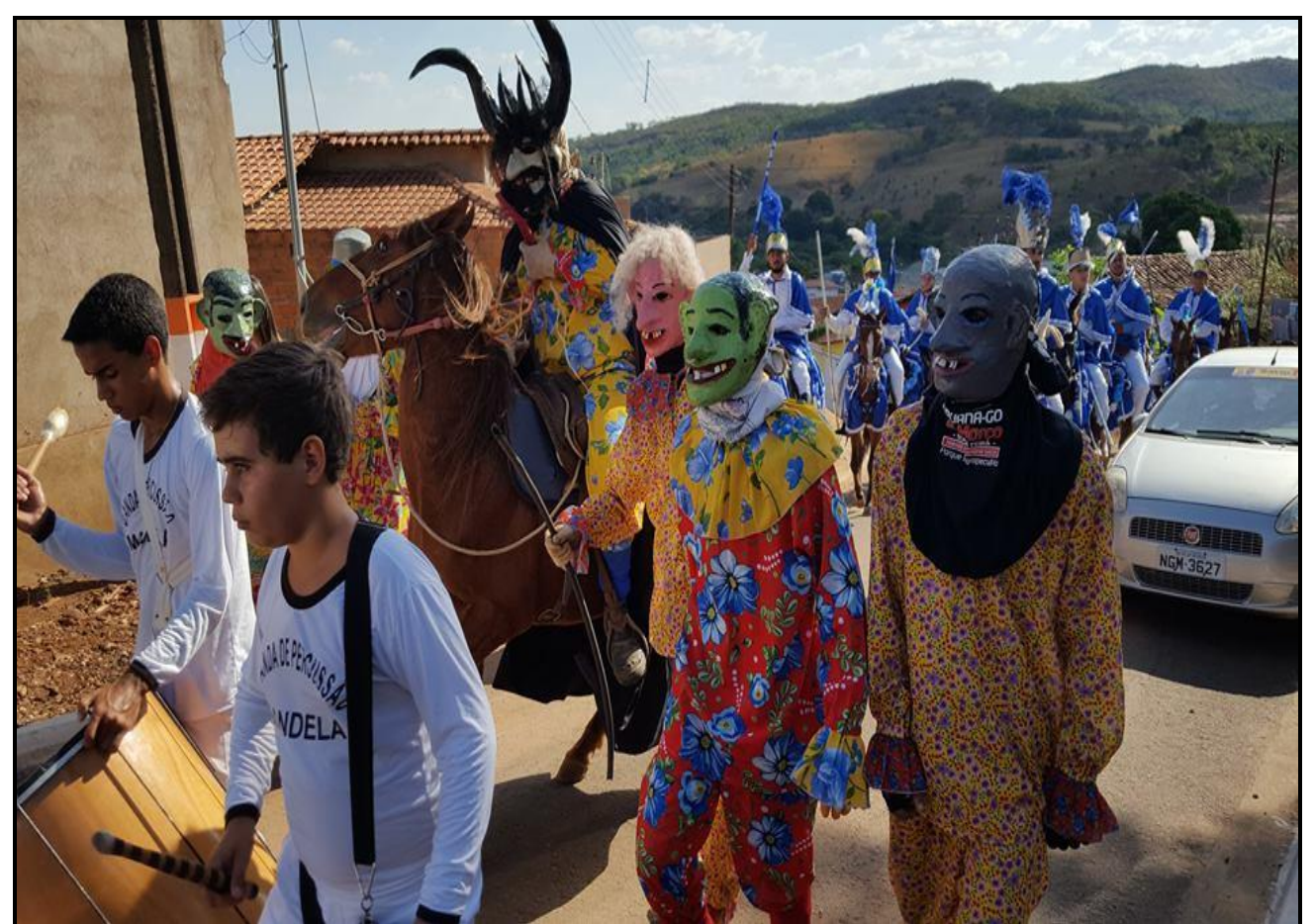

Figure 4. Masked and Knights in the Direction of the Cavalhadas Field, in Pilar de Goiás (Goiás, Brazil)

Source: Rogério Ferreira, 2015. 


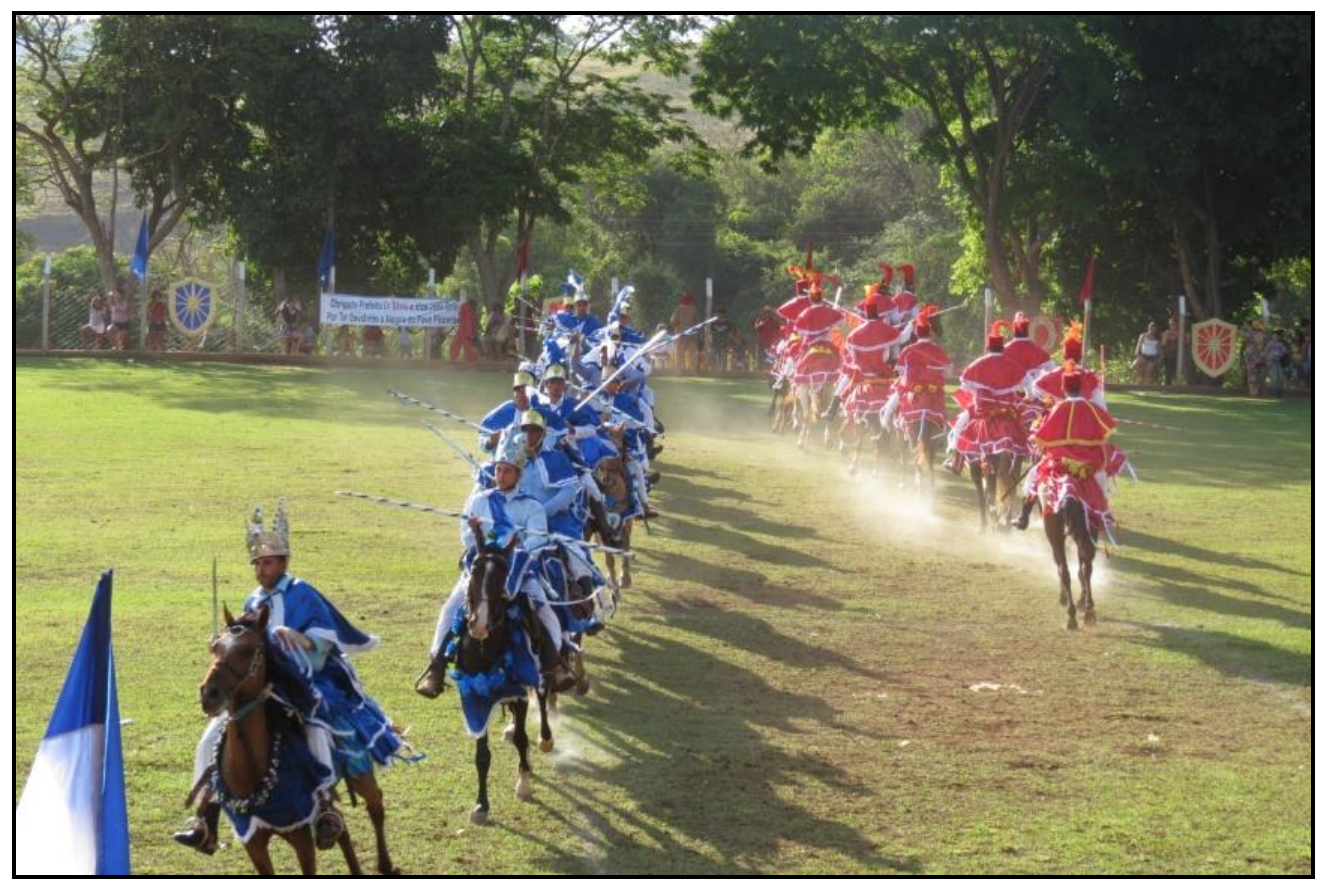

Figure 5. Presentation of the Cavalhadas, in Pilar de Goiás (Goiás, Brazil) Source: Luana Nunes Martins de Lima, 2014.

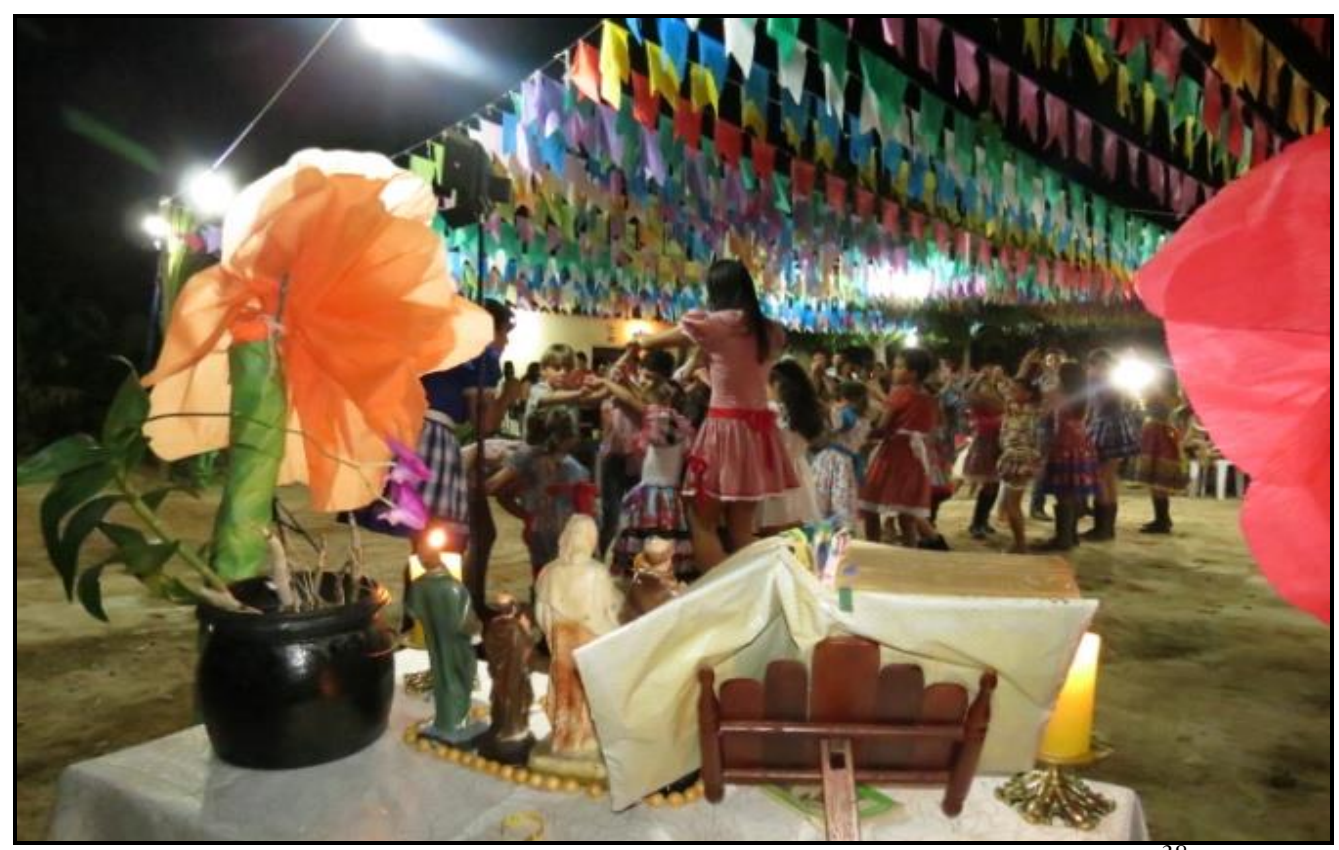

Figure 6. Altar to Santo Antônio, São João e São Pedro, Quadrilha ${ }^{38}$ in the Arraiá da Boa Vizinhança, in Porangatu (Goiás, Brazil)

Source: Luana Nunes Martins de Lima, 2015

38. In Brazil, the "Quadrilha" is a popular dance typical of the celebrations of the June festivals. It is characterized by steps rehearsed and performed by couples, who are animated by a narrator who commands the movements of the dance. Traditionally, it was agreed to use the stereotypical image of the country man ("caipira") as the central character. According to anthropologists and historians, the Quadrilha would have arisen in Brazil even during the colonial period. 


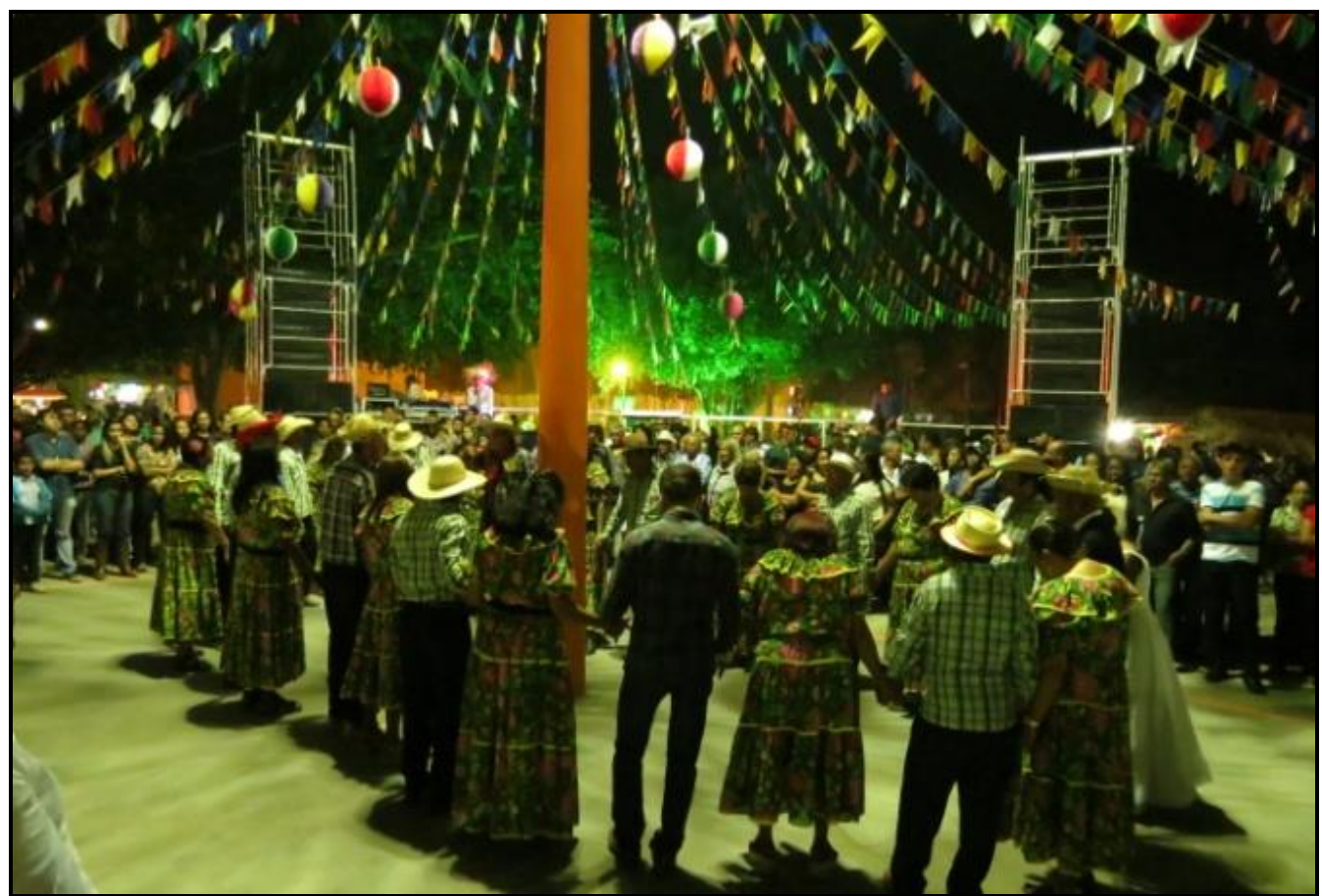

Figure 7. Quadrilha of Third Age in the Arraiá do Descoberto, in Porangatu (Goiás, Brazil)

Source: Luana Nunes Martins de Lima, 2015.

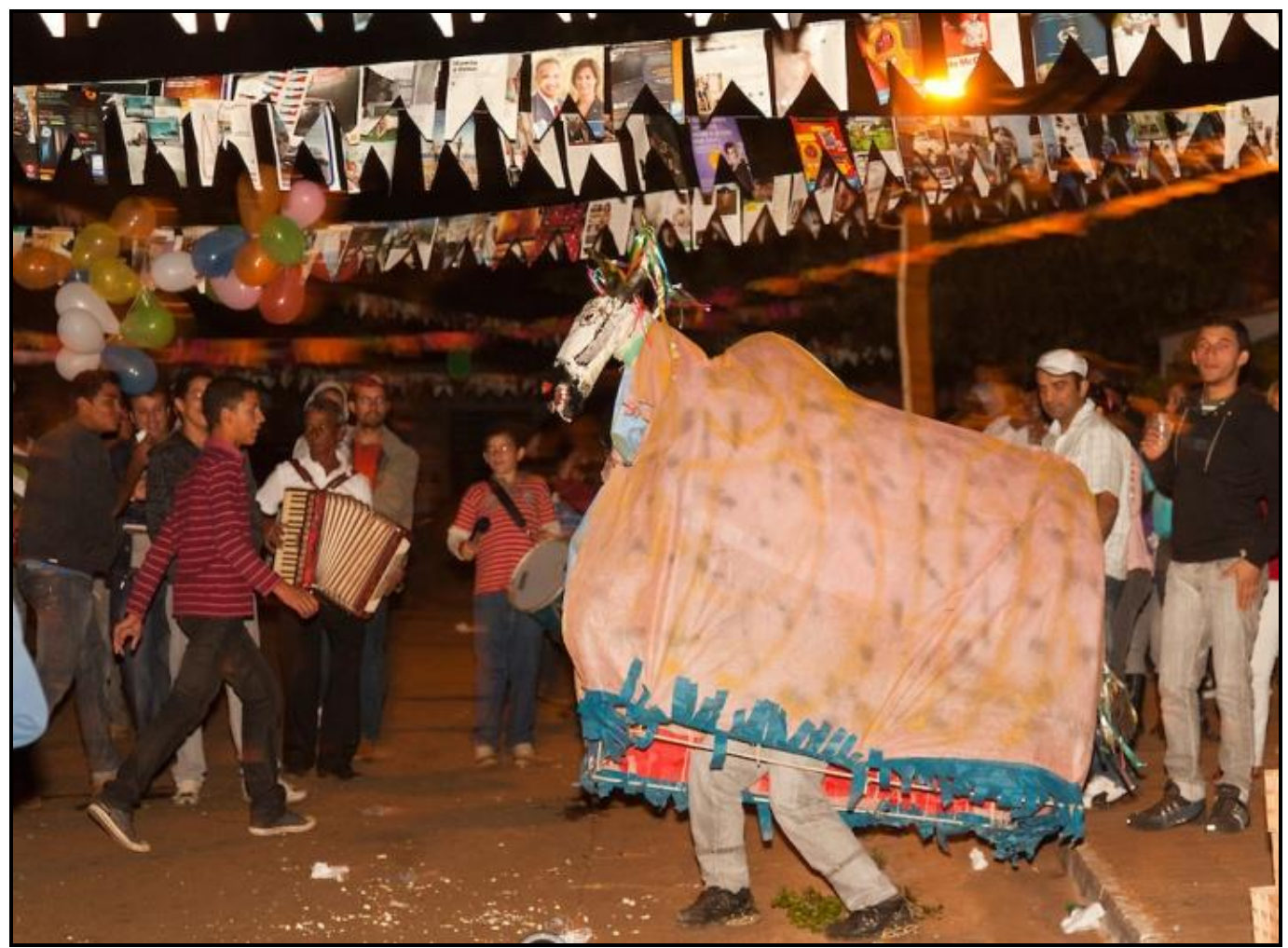

Figure 8. The Ox's Play ("Boi de São João"), Feast of São João. Devotion of Luciano Correia de Brito, in Pilar de Goiás (Goiás, Brazil) Source: Marcos Issa, 2011. 


\section{Conclusions}

In this paper, we seek to establish a dialogue between the forgetfulness in relation to the historical heritage of Goiás, largely unrecognized institutionally, or recognized only selectively and partially, and memory, which has in itself the recognition and apprehension of the past, as an element that still guides the present in the cities. Therefore, we must emphasize that heritage conservation alone is not capable of feeding the senses that heritage carries. Conservation sometimes only brings nostalgic compensation, we see that the risk of forgetfulness engenders guilt and legitimizes the projects of revisiting history, which, in people's excessive search for their roots, annul the present life ${ }^{39}$.

Although the historic heritage does not remain in materiality, or is not to be included in national patrimonial projects, we consider that it remains in the lived, in the symbolic values, in the memories and in the experience, and may even be local, small, in the community and even familiar, in case of the cities under analysis. Examples are the festivities held for decades and even centuries in these cities.

Even so, when heritage remains in materiality, memory is far more prominent for that place than if it were absent, or constituting only as ruins in urban spaces. For her, "this daily tension between transformation and resistance is part of the dialectic of the modern spirit" ${ }^{40}$.

The heritage in Goiás has been regarded in two scales that are related dialectically. The first, in a movement from the abstract to the empirical, concerns the modernization of Goiás territory, which has shaped urban space and led many places of heritage to forgetfulness. The second scale, in a movement from the empirical to the abstract, refers to the place in heritage cities, where the resistances are identified, although they are not always on the plane of the material. The two scales are dialectical, because within a place supposedly "forgotten" on the scales that are beyond the limits of the place lived, or in ruins, the patrimony is revealed.

In short, the cultural heritage that resists in these cities is the affirmation of heritage denied historically. And the sense of "place" is the negation of "forgetfulness", evidencing that there is no total "forgetfulness", since the heritage has been affirmed by people uninterruptedly in the traditions, values, ruralities, secular practices that that lasted for a long time, even without any registration and visibility.

39. H.-P. Jeudy, Espelho das cidades [Mirror of cities] (Rio de Janeiro: Casa da Palavra, 2005), 15 .

40. E. Bosi, O tempo vivo da memória: ensaios de psicologia social [The living time of memory: social psychology essays] (São Paulo: Ateliê Editorial, 2003), 206. 


\section{References}

Bosi, E. O tempo vivo da memória: ensaios de psicologia social [The living time of memory: social psychology essays]. São Paulo: Ateliê Editorial, 2003.

Brandão, C. R. Pesquisar-Participar [Research-Participate]. São Paulo: Brasiliense, 1990.

Brandão, C.R. "De um lado e do outro do mar: festas populares que uma origem comum aproxima e que um oceano e um cerrado separam" ["On one side and the other on the sea: popular festivities that a common origin approaches and that an ocean and a cerrado separete"]. In Festas, religiosidades e saberes do Cerrado, edited by M. de Fátima Oliveira et al., 25-72. Anápolis: UEG, 2015.

Buttimer, A. "Grasping the dynamism of lifeworld". In Annals of the Association of American Geographers 66 (1976): 277-292.

Chaveiro, E.F. "A Urbanização do Sertão Goiano e a Criação de Goiânia" ["The Urbanization of the Sertão of Goiás and the creation of Goiânia"]. In $O$ Espaço Goiano: abordagens geográficas, edited by H. Gomes, 93-144. Goiânia: AGB, 2004.

Choay, F. A alegoria do patrimônio [The allegory of heritage]. São Paulo: UNESP, 2001.

Costa, Everaldo Batista. Cidades da Patrimonialização Global: simultaneidade totalidade-urbana - totalidade-mundo [Cities of Global Heritage: simultaneity totality-urban - totality-world]. São Paulo: Humanitas, 2015.

Costa, E. B. and Suzuki, J. C. "A ideologia espacial constitutiva do Estado nacional brasileiro" ["The constitutive spatial ideology of the Brazilian national state"]. Scripta Nova - Revista Electrónica de Geografía y Ciencias Sociales XVLI, no. 418 (6) (2012).

Delgado, L. de Almeida Neves. História Oral: memória, tempo, identidade [Oral History: memory, time, identities]. Belo Horizonte: Autêntica, 2010.

Di Méo, G. La géographie en fêtes [The geography in the feasts]. Paris: OPHRYS, 2001.

Eckert, C. "A saudade em festa e a ética da lembrança" ["The homesick in celebration and the ethic of remembrance"]. Estudos Feministas 5, no. 1 (1997): 182-192.

Flick, U. Introdução à pesquisa qualitativa [Introduction to qualitative research]. Porto Alegre: Artmed, 2009.

Freitas, Lena Castello Branco Ferreira de. "Goiás e Goianidade" ["Goiás and Goianity"]. In Aphonline 1, no.1 (2011): 52-64.

Instituto Brasileiro de Geografia e Estatística (IBGE). Cidades [Cities], 2010. https://cidades.ibge.gov.br. Accessed January 17, 2015.

Jeudy, H.-P. Espelho das cidades [Mirror of cities]. Rio de Janeiro: Casa da Palavra, 2005.

Lozano, J. E. Aceves. "Prática e estilos de pesquisa na história oral contemporânea" ["Practice and styles of research in contemporary oral history"]. In Usos e abusos da história oral [Uses and abuses of oral history], edited by M. de Moraes Ferreira e Janaína Amado, 15-25. Rio de Janeiro: FGV, 2006.

Marconi, M. de Andrade and Lakatos, E.M. Metodologia científica [Scientific methodology]. São Paulo: Atlas, 2004.

Martins, J. de Souza. Sociologia da Fotografia $e$ da Imagem [Sociology of Photography and Image]. São Paulo: Contexto, 2008.

Melo, R.V. "Cerimônias comemorativas em Corumbá de Goiás" ["Commemorative ceremonies in Corumbá de Goiás"]. In Entorno que transborda: patrimônio imaterial da RIDE, edited by Thereza Ferraz Negrão de Mello, 143-171. Brasília: Petrobrás, 2008. 
Paes, M.T. Duarte."Trajetórias do patrimônio cultural e os sentidos dos seus usos em Paraty (RJ)" ["Trajectories of cultural heritage and the meanings of its uses in Paraty (RJ)"]. Resgate - Revista Interdisciplinar de Cultura 23, no. 30, (2015): 105-118.

Relph, E.W. Place and Placelessness. Londres: Pion, 1979.

Santos, M. A natureza do espaço: Técnica e Tempo, Razão e Emoção [The Nature of Space: Technique and Time, Reason and Emotion]. São Paulo: USP, 2006.

Tuan, Y. F. Topofilia: Um estudo da percepção, atitudes e valores do meio ambiente [Topophilia: A study of the perception, attitudes and values of the environment]. Londrina: Eduel, 2012.

Tuan, Y.F. Espaço e lugar: a perspectiva da experiência [Space and place: the perspective of experience]. Londrina: Eduel, 2013.

UNESCO. Convention for the Safeguarding of the Intangible Cultural Heritage. Paris, 2003. 